\section{EPISTEMOLOGICAL STUDIES IN PHILOSOPHY, SOCIAL AND POLITICAL SCIENCES \\ ISSN 2618-1274 (Print), ISSN 2618-1282 (Online) \\ Journal home page: https://visnukpfs.dp.ua/index.php/PFS/index}

\section{Вікторія Юріївна Антонова}

Кандидат філософських наук, доцент Доцент кафедри гуманітарної підготовки, філософії та ідентифікації культурних цінностей, Університет митної справи та фінансів, вул. В.Вернадського 2/4, м. Дніпро, Україна E-mail: batumi1508@gmail.com,

\section{Олександр Миколайович Корх}

Доктор філософських наук, професор Професор кафедри гуманітарної підготовки, філософії та ідентифікації культурних цінностей, Університет митної справи та фінансів, вул. В.Вернадського 2/4, м. Дніпро, Україна

E-mail: korh54@gmail.com,

\section{Viktoria Antonova}

Pr.D.Associate Professor,

Department of humanitarian training, philosophy and customs identification of cultural values,

University of Customs and Finance,

Vernadskogo Str., 2/4, Dnipro, Ukraine

ORCID ID: https://orcid.org/0000-0003-0244-4142

\section{Oleksandr Korkh}

Doctor of Philosophical Sciences,

Professor of the Department of humanitarian training, philosophy and customs identification of cultural values, University of Customs and Finance, Vernadskogo Str., 2/4, Dnipro, Ukraine ORCID ID: https://orcid.org/0000-0001-7175-5011

УДК 1:39

\title{
МЕТОДОЛОГІЧНИЙ АСПЕКТ АНАЛІЗУ ЕТНІЧНОГО
}

Received 05 September 2020; revised 10 October 2020; accepted 30 October 2020 DOI: $10.15421 / 342027$

\section{Анотація}

Глобалізаційні прочеси, щуо стали визначальним трендом сучасного світу, супроводжуються активізацією різноманітних етно-регіональних рухів. Це викликає зрозумілу увагу до етносоціальної проблематики. Цілком природним при иьому є звернення до питань методологічного характеру. Попри значну кількість досліджень в межах даного проблемного поля, консенсусу щодо розуміння етнічного та конщептуальних засад його осмислення на даний час не спостерігається. Відтак основною метою даної статті є окреслення методологічних засад аналізу феномену етнічного, щзо сприятиме максимально адекватній експлікаиії різних аспектів відповідного проблемного поля. Аналіз наявних в науковому дискурсі філософських, культурологічних, етнологічних тощо інтерпретацій поняття етнічного, створив підстави для авторської його інтерпретації як відносно сталої сукупності лінгвістичних, релігійних, психологічних, культурних, територіально-історичних тощяо характеристик та самоідентифікачій, що слугують смисловим ядром консолідачії того чи іншого етносу та, водночас, виокремлення його з-поміж інших. Таке розуміння не претендує на універсальність та завершеність $i$ виступає лише засобом подальшого аналізу етнічного шияхом співвіднесення дійсності з иією рачіональною моделлю. В одних випадках зазначені в ній характеристики можуть домінувати. В інших - виступати в латентній або й взагалі деформованій формі, що й створює підстави для суттєво відмінних інтерпретачій феномена етнічного, які здійснюються до того ж з різних методологічних позииій. Останні, з огляду на багатогранність проблеми етнічного та принципове різноманіття способів пізнання, иілкком природні. Однак найбільша користь від їхнього використання можлива лише вразі його комплексного характеру.

Ключові слова: етнічне, методологічний аспект, моделі інтерпретації, комплексний підхід.

\section{Methodological aspect of ethnic analysis}

\section{Abstract}

The processes of globalization, which have become a defining trend in the modern world, are accompanied by the activation of various ethno-regional movements. This arouses the particular attention to ethnosocial issues. It is obvious that the questions of a methodological nature appears. After all, only from the path of understanding these questions depends the ethnic problem field issue statement and solution. Despite 
a significant amount of research within this problem field, currently there is no consensus regarding the understanding of the ethnic and conceptual foundations of its conceptualization. Therefore, the main purpose of this study is to determine the methodological analysis framework of the phenomenon of ethnic, which will contribute to the most adequate explication of various aspects of the corresponding problem area. Analysis of the philosophical, cultural, ethnological, etc. interpretations of the concept of ethnicity, which are available in the scientific discourse, created the basis for the authorial interpretation of it as a relatively constant set of linguistic, religious, psychological, cultural, territorial-historical, etc. characteristics and self-identifications, which serve as the semantic core of the consolidation of one or another ethnic group and, at the same time, distinguishing it from others. This type of understanding does not claim to be universality and completeness and serves only as a further analysis of the ethnic by correlating reality with this rational model. Therefore, it cannot be completely identified with a current reality. In some cases, the characteristics specified in it may dominate. In others - to serve in a latent or even distort form, which causes the significantly different interpretations of the phenomenon of ethnic, implemented from different methodological positions. These views according to the complexity of the problem of ethnic and the fundamental diversity of methods of cognition are quite natural. Nonetheless, the greatest benefit from their use is possible only through its integrated nature. This, in turn, requires a clear position on the «meta-basis» of this complexity and a clear awareness of the synergistic nature of ethnicity and ethnicity phenomena.

Key words: ethnic, methodological aspect, interpretation models, complex approach.

\section{Методологический аспект анализа этнического Аннотация}

Глобализационные процессы, которые стали определяющим трендом современного мира, сопровождаются активизачией различных этно-региональных движений. Это обуславливает особое внимание к этносоииальной проблематике. Вполне естественным при этом является обращение $к$ вопросам методологического характера. Несмотря на значительное количество исследований в рамках данного проблемного поля, консенсуса относительно понимания этнического и концептуальных основ его осмысления в настоящее время не наблюдается. Поэтому основной целью данного исследования является определение методологических основ анализа феномена этнического, что будет способствовать максимально адекватной экспликации различных аспектов соответствующего проблемного поля. Анализ имеющихся в научном дискурсе философских, культурологических, этнологических и т.д. интерпретаций понятия этнического, послужсил основанием для авторской его интерпретации как относительно стабильной совокупности лингвистических, религиозных, психологических, культурных, территориально-исторических характеристик и самоидентификаций, которые служат смысловым ядром консолидации того или иного этноса и, в то же время, выделения его среди других. Такое понимание не претендует на универсальность и завершённость и выступает лишь средством дальнейшего анализа этнического путём соотнесения действительности с этой рачиональной моделью. В одних случаях указанные в ней характеристики могут доминировать. В других - выступать в латентной или вообще деформированной форме, что и создает основания для существенно отличающихся интерпретаций феномена этнического, которые осуществляются при этом с различных методологических позиций. Последние, учитывая многогранность проблемы этнического и принципиальное многообразие способов познания, вполне естественны. Однако наибольшая польза от их использования возможна только в случае его комплексного характера.

Ключевые слова: этническое, методологический аспект, модели интерпретации, комплексный nодxод.

\section{Постановка проблеми}

Безумовним фактом сьогодення є посилення глобалізаційних процесів, яке, однак, супроводжується значною активізацією різноманітних етно-регіональних рухів. 3 огляду на це все більшої актуальності набуває етносоціальна проблематика. Характер осмислення, а відповідно і розв'язання цієї проблематики значною мірою залежить від способу та результатів філософської експлікації ключових в контексті даної проблематики понять, насамперед поняття «етнічного». Попри те, що чимало мислителів минулого зверталося до його аналізу, це поняття так і не отримало 
належної логічно несуперечливої концептуалізації, відтак потребує подальшого осмислення та уточнення. У тому числі з огляду на нові соціокультурні реалії та методологічні парадигми, що цілком природно з огляду на історичний характер будь-якої категорії. Тим більше такої, яка стосується інтересів без перебільшення кожної людини як репрезентанта того чи іншого етносу.

\section{Аналіз стану дослідження}

Ретроспективний погляд свідчить про існування чисельних спроб осмислення сутності етнічного. Йдеться зокрема про роботи Гегеля, Гердера, Фіхте, які показали багатогранність буття етнічного. До осмислення метафізичного його аспекту були причетні Гайдеггер, Гумбольдт, Гусерль, Дільтей, Тойнбі та інші західні дослідники. Серед представників вітчизняної думки варто, на наш погляд, згадати передусім М.Грушевського, М.Драгоманова, П.Куліша, М.Костомарова, I. Мірчука та інших, які актуалізували проблему етнічного у вітчизняному контексті. Досить продуктивно, зокрема щодо характерних рис буття власне українського етносу, проблема етнічного висвітлюється в роботах П.Гнатенка, М.Поповича, Н.Яковенко та інших вітчизняних дослідників.

Наукова думка перших десятиліть XXI століття також демонструє неабияку увагу щодо феномену етнічного, причому, нерідко 3 акцентом на методологічному аспекті його аналізу. Так, зокрема, на необхідність переосмислення етнічного на основі нових теоретико-методологічних підходів звертається увага в дослідженні М.Папастефану «Деконструкція етносу - національна відмінність» [Papastephanou 2012]. Спираючись на компаративістську методологію розглядає проблему збереження цілісного буття етносу в умовах глобалізації А. Демосфенус [Demosthenous 2016]. А колектив авторів, до складу якого входять А.Лукжанов, М.Пушкарьова та інші, в основу власного аналізу онтології етносу поклав метод інтуїції [Lukjanov 2018]. Цікавими спробами розкрити сутність етнічного за допомогою особливої інтерпретації та структурного аналізу є дослідження О.Рудакевича «Національний принцип: етнополітич- на концепція нації» [Рудакевич 2009], а також робота В.Фадєєва, Г.Носова, В.Багінського та Б.Попова «Етнічний вимір соціокультурних перетворень» [Фадєєв 2016]. Заслуговує на увагу і дослідження О. Титар, яка зробила спробу аналізу етнічного через призму синергетики [Титар 2016].

Використання як зазначеними, так і іншими дослідниками різних, а в окремих випадках і нетрадиційних для даного проблемного поля методів, а також відсутність єдиного підходу до тлумачення центрального в даному проблемному полі поняття етнічного цілком логічно ставить питання щодо їх ефективності, надійності, а відтак і прийнятності. Саме тому, метою даного дослідження є окреслення методологічних засад аналізу феномену етнічного, що сприятиме максимально адекватній експлікації різних аспектів цього вкрай важливого і непростого проблемного поля.

Виклад основного матеріалу дослідження

Будь-яке наукове дослідження має базуватися на продуманих методологічних засадах, якими виступають передусім вихідні поняття та принципи. Що стосується першого, то авторський підхід до розуміння ключового, в даному проблемному полі, поняття, який базується на попередньому узагальненні значної кількості філософських, культурологічних, етнологічних тощо його інтерпретацій, полягає в наступному. Етнічне в його найбільш загальному розумінні розглядається як відносно стала сукупність лінгвістичних, релігійних, психологічних, культурних, територіально-історичних тощо характеристик та самоідентифікацій, що слугують смисловим ядром консолідації того чи іншого етносу та, водночас, виокремлення його з-поміж інших. Таке тлумачення етнічного виступає як своєрідна теоретична модель на зразок «ідеального типу» М. Вебера, що представляє собою теоретичний конструкт, створений на основі синтезу існуючих, звісно достатньо обгрунтованих, моделей його інтерпретації. Йдеться зокрема про «міфопоетичну модель» Е.Сміта, який акцентував на визначальній ролі міфів і символів, що передаються від покоління до покоління, в збереженні та відтво- 
ренні етнічної цілісності [Smith Anthon 1986]; про «субстратно-характеристичну модель» Л.Гумільова, з іiї акцентом на способі життя (побуту) та поведінки як системо утворюючій основі різноманітних проявів і характеристик етнічного [Гумилев 2004]; про так звану «функціональну модель» Ю.Бромлея, що грунтується на визнанні існування і функціонування деяких «єдиних законів», яким підпорядкований і генезис етнічного [Бромлей 1987].

Підкреслимо, що авторська модель не претендує апріорі на універсальність та завершеність. Автори поділяють ідею фалібілізму К.Поппера, згідно якої усі наукові концепти принципово не є остаточними, вони є лише проміжними інтерпретаціями істини, які передбачають наступну заміну на кращі інтерпретації. Тобто, ця модель виступає лише засобом подальшого аналізу відповідного феномена шляхом співвіднесення дійсності 3 цією моделлю. Відтак, її не можна повністю ототожнювати 3 конкретною реальністю. В одних випадках зазначені в ній характеристики можуть домінувати. В інших - виступати в латентній або й взагалі деформованій формі, що й створює підстави для суттєво відмінних інтерпретацій феномена етнічного в різних філософсько-теоретичних рефлексіях. Попри це запропонована модель створює, на наш погляд, необхідні передумови для подальшої концептуалізації предмета дослідження. Важливу роль в цій концептуалізації мають відігравати «старі але надійні» діалектичні принципи, насамперед всезагального зв'язку, розвитку та діалектичних суперечностей як головного його джерела. Саме використання цих принципів дозволяє сформулювати найбільш загальні уявлення про природу етносу та етнічного, їхне місце серед інших соціокультурних форм, їх спільну динаміку та рушійні сили, системний характер вказаних характеристик етнічного тощо. Іншими словами, в найбільш загальному плані спрямувати вирішення фундаментальних питань проблемного поля етнічного. Отже, застосування зазначених принципів створює реальну «метаоснову» для відбору та використання всіх інших методів, а також інтерпретації резуль- татів їхнього застосування.

Створення вище зазначеної моделі $\epsilon$ важливою умовою звернення до принципу єдності історичного та логічного, який вимагає, з одного боку, постійно співвідносити аналіз історії становлення і розвитку об'єкта пізнання з його логіко-теоретичною моделлю; а 3 іншого - логіко-теоретичну реконструкцію етнічного неодмінно пов'язувати 3 аналізом його реального історичного розвитку. Іншими словами, використання даного принципу дозволяє в ході аналізу генезису конкретноісторичних форм етнічного виокремити та концептуалізувати його відносно константну i, зрозуміло, ідеалізовану сутність, оприявнену через сукупність відносно сталих, загальних та необхідних його ознак. Уявлення про суттєве в свою чергу повинні бути враховані в подальшій експлікації феномена етнічного, у тому числі в його історичній площині. Ця експлікація вимагає свідомого використання методу сходження від абстрактного до конкретного, яке дозволяє перейти від абстрактних i тому «бідних» уявлень про етнічне до знань все більш конкретних i змістовних. Тобто, осмислити не лише сутність етносу в його найбільш загальному сенсі, а й своєрідність конкретно-історичних форм ï існування. Завдяки цьому, зокрема, метафізичний «дух народності» постає в дійсно змістовних формах, доступних для подальшого порівняння, аналізу, синтезу та узагальнення.

Безумовно важлива роль, на нашу думку, має належати системному методу, який орієнтує на розгляд етнічного як складної цілісної системи, якій притаманні власні системні характеристики та закономірності. Зрозуміло, що використання цього методу в дослідженні етнічного щільно пов'язане 3 структурно-функціональним ракурсом його осмислення, завдяки якому стає можливим, 3 одного боку - виокремлення та експлікація головних структурних складових етносу, a 3 іншого - осмислення їх зв'язків та ролі (функцій) у складі цілого. Усе це придає уявленням про етнічне концептуальної єдності, здатної зафіксувати та експлікувати зазначену цілісність, відтак мінімізувати 
недоліки позасистемного бачення етносу як об'єкта дослідження в цілому, так і окремих його складових - мови, релігії, менталітету тощо.

Вкрай продуктивним для осмислення етнічного $\epsilon$ i компаративний метод, оскільки типологічні ознаки будь-якого явища виявляються лише у багатобічному його співвідношенні 3 іншими явищами, тобто у порівнянні. Останнє особливо плідне в разі його проведення як в площині синхронного, так і в площині діахронного, оскільки дозволяє порівнювати специфіку паралельно співіснуючих етносів, а також своєрідність різних етапів їх історичного розвитку. Застосування цього методу особливо актуальне в контексті сучасного міжкультурного діалогу, умовах глобалізації та незбутих стратегій мультикультуралізму. Слід при цьому мати на увазі, що важливою умовою адекватного аналізу феноменів модерних культур $€$ неприпустимість їх зведення до якихось виключно автохтонних, замкнутих у собі, самодостатніх форм. Адже зміст переважної їх більшості формується в процесі співіснування і все більш активного взаємопроникнення різних культур. Безумовно, стосується це і вітчизняної культури, принципово гетерогенної і полінаціональної.

Останнім часом у вітчизняному науковому та філософському дискурсі все частіше звертаються до герменевтичного методу, який дозволяє 3 певною мірою наближення реконструювати розуміння певного явища у визначеному культурно-історичному контексті шляхом тлумачення відповідних текстів, більш широко - будь-яких артефактів, що репрезентують даний контекст. Слід при цьому усвідомлювати те, що автентичне ïx розуміння можливе лише за умови «включення» дослідника до цього контексту, тобто лише за умови, що дослідник вживеться в кимось написане і зможе побачити те, що приховано за сказаним. За словами Гадамера таке розуміння вимагає від дослідника максимально чіткого усвідомлення де і коли відповідні судження були висловлені, якою була їх мотивація, а відповідно і яким $\epsilon$ притаманний їм сенс [Гадамер 1988].

Звісно, що все це вимагає глибокого розуміння мовної традиції, більш широко всього культурного контексту, який склався в ту чи іншу епоху, володіння мистецтвом інтерпретації текстів, а також розвинутої інтуїції. Тобто речей, які створюють сприятливий грунт для множинності інтерпретацій. 3 огляду на це важливим представляється звернення дометодологічного потенціалу робіт Г.Гадамера [Гадамер 1988], П.Рікьора [Рикер 1995], Г.Ріккєрта [Риккерт 1997] та інших дослідників.

\section{Висновки}

Аналіз наявних в науковому дискурсі філософських, культурологічних, етнологічних тощо інтерпретацій поняття етнічного, дає підстави розглядати його як відносно сталу сукупність лінгвістичних, релігійних, психологічних, культурних, територіально-історичних тощо характеристик та самоідентифікацій, що слугують смисловим ядром консолідації того чи іншого етносу та, водночас, виокремлення його з-поміж інших. Таке розуміння не претендує на універсальність та завершеність і виступає лише засобом подальшого аналізу етнічного шляхом співвіднесення дійсності з цією раціональною моделлю. Відтак, iii не можна повністю ототожнювати 3 конкретною реальністю. В одних випадках зазначені в ній характеристики можуть домінувати. В інших - виступати в латентній або й взагалі деформованій формі, що й створює підстави для суттєво відмінних інтерпретацій феномена етнічного, які здійснюються до того ж 3 різних методологічних позицій. Останні, 3 огляду на багатогранність проблеми етнічного та принципове різноманіття способів пізнання, цілком природні. Однак найбільша користь від їхнього використання можлива лише вразі його комплексного характеру. Це, в свою чергу, вимагає чіткого позиціювання щодо «метаоснови» цієї комплексності та не менш чіткого усвідомлення синергетичного характеру феноменів такого рівня як етнос та етнічне. Для цього вельми корисною була б подальша експлікація онтології етнічного саме 3 позицій синергії. 


\section{Бібліографічні посилання}

Багінський, В.В., Носова, Г.Ю., Попов, Б.В., Фадєєв, В.Б. (2016). Етнічний вимір соиіокультурних перетворень: монографія. К.

Бромлей, Ю.В. (1987). Этносочиальные проиессы: теория, история, современность. М.

Гадамер, Х.-Г. (1988). Истина и метод: Основы философской герменевтики. М.

Гумилев, Л.Н. (2004). Этносфера : история людей и история природы. М.

Рикер, П. (1995). Конфликт интерпретаций. Очерки о герменевтике. М.

Риккерт, Г. (1997). Границь естественнонаучного образования понятий. Логическое введение в исторические науки. Санкт-Петербург.

Рудакевич, О.М. (2009). Національний принции: етнополітична концепція нації. Тернопіль.

Титар, О.В. (2016). Украӥнські національно-культурні ідентичності Слобожсанщини у контексті глобалізацї̈: філософсько-антропологічний вимір: Автореф. дис. ... докт. філос. наук, спеціальність 09.00.04 - філософська антропологія, філософія культури. - Харків.

Demosthenous, Areti. (2016). Challenges to Ethnos ( $\dot{\varepsilon} \theta v o \varsigma)$ in a Global Society, Colloquia Humanistica, 5 , 104-126. [Електронний ресурс]. Режим доступу: https://ispan.waw.pl/journals/index.php/ch/article/ view/ch.2016.008 (дата звернення 25.08.2020)

Lukjanov, A., Pushkareva, M., Rakhmatullina, Z., Itkulova, L. (2018). Concerning new social ontology of ethnos as historical consciousness and self-identity, International Journal of Ethics and Systems. 213220. [Електронний ресурс]. Режим доступу: https://www.researchgate.net/publication/325435659 Concerning new social ontology of ethnos as historical consciousness and self-identity (дата звернення 20.08.2020)

Omelaenko, N. (2019). Concepts of Ethnos and Nation in Scientific and Theoretical Studies, Proceedings : International Scientific Conference "Far East Con, Advances in Economics, Business and Management Research, 47, 202-207. [Електронний ресурс]. Режим доступу: https://download.atlantis-press.com/ article/55912373.pdf (дата звернення 23.07.2020)

Papastephanou, M. (2012). Deconstructing the Ethnos - Nation Distinction, Journal of Politics and Law, 5(4), P.147-158. [Електронний ресурс]. Режим доступу: http://www.ccsenet.org/journal/index.php/jpl/ article/view/22552 (дата звернення 25.07.2020)

Smith Anthony. ( 1986). The Ethnic Origins of Nations. Oxford : Blackwell. [Електронний ресурс]. Режим доступу: https://www.wiley.com/en-us/The+Ethnic+Origins+of+Nations-p-9780631161691 (дата звернення 21.08.2020)

\section{References}

Bagins'kij, V.V., Nosova, G. Ju., Popov, B.V. \& Fadeev, V.B. (2016). Etnichnij vimir sociokul 'turnih peretvoren' [Ethnic dimension of sociocultural transformations]: monograph. K. (in Ukrainian)

Bromlej, Ju.V. (1987). Etnosocial'nye processy: teorija, istorija, sovremennost'[Ethnosocial processes: theory, history, modernity]. M. (in Russian)

Demosthenous, Areti. (2016). Challenges to Ethnos ( $\dot{\theta} \theta v o \varsigma)$ in a Global Society, Colloquia Humanistica, 5 , 104-126. Retrived August 25, 2020 from https://ispan.waw.pl/journals/index.php/ch/article/view/ ch.2016.008

Gadamer, H.-G. (1988). Istina i metod: Osnovy filosofskoj germenevtiki [Truth and Method: Fundamentals of Philosophical Hermeneutics]. M. (in Russian)

Gumilev, L. N. (2004). Etnosfera: istorija ljudej i istorija prirody. [Ethnosphere: history of people and history of nature]. M. (in Russian)

Lukjanov, A., Pushkareva, M., Rakhmatullina, Z., Itkulova, L. (2018). Concerning new social ontology of ethnos as historical consciousness and self-identity, International Journal of Ethics and Systems. 213-220. Retrived August 20, 2020 from https://www.researchgate.net/publication/325435659 Concerning_new_social_ontology_of ethnos_as historical_consciousness_and_self-identity

Omelaenko, N. (2019). Concepts of Ethnos and Nation in Scientific and Theoretical Studies, Proceedings : International Scientific Conference "Far East Con, Advances in Economics, Business and Management Research, 47, 202-207. Retrived Jule 23, 2020 from https://download.atlantis-press.com/ article/55912373.pdf

Papastephanou, M. (2012). Deconstructing the Ethnos - Nation Distinction, Journal of Politics and Law, 
5(4), P.147-158. Retrived Jule 25, 2020 from http://www.ccsenet.org/journal/index.php/jpl/article/ view/22552

Riker, P. (1995). Konflikt interpretacij. Ocherki o germenevtike [Conflict of interpretations. Essays on hermeneutics]. M. (in Russian)

Rikkert, G. (1997). Granicy estestvennonauchnogo obrazovanija ponjatij. Logicheskoe vvedenie v istoricheskie nauki [The boundaries of the natural science education of concepts. A logical introduction to the historical sciences]. St. Petersburg. (in Russian)

Rudakevich, O.M. (2009). Nacional'nij princip: etnopolitichna koncepcija naciji [National principle: ethnopolitical concept of the nation]. Ternopil. (in Ukrainian)

Smith Anthony. ( 1986). The Ethnic Origins of Nations. Oxford : Blackwell. Retrived August 21, 2020 from https://www.wiley.com/en-us/The+Ethnic+Origins+of+Nations-p-9780631161691

Titar, O.V. (2016). Ukrajins'ki nacional'no-kul'turni identichnosti Slobozhanshhini u konteksti globalizaciji: filosofs'ko-antropologichnij vimir [Ukrainian national and cultural identities of Slobozhanshchina in the context of globalization: philosophical and anthropological dimension]. Authorial abstract, doctor of philosophical science, speciality 09.00 .04 - philosophical anthropology, philosophy of culture. Kharkiv. (in Ukrainian) 